\title{
Aliran Penanaman Modal Asing dan Dampaknya terhadap Pertumbuhan Ekonomi Indonesia
}

\author{
Amiruddin \\ Program Studi Pendidikan Ekonomi, Universitas Syiah Kuala \\ e-mail: amiruddin@unsyiah.ac.id
}

\begin{abstract}
Abstrak
Penelitian ini bertujuan untuk menjelaskan dampak aliran penanaman modal asing terhadap pertumbuhan ekonomi di Indonesia sejak 2004-2017. Metode yang digunakan dalam studi ini merupakan metode deskriptif kuantitatif dengan menggunakan data sekunder yang bersumber dari publikasi World Bank. Hasil Penelitian menunjukkan bahwa, aliran PMA berpengaruh positif dan signifikan terhadap pertumbuhan ekonomi dan nilai koefisien determinasi dapat menjelaskan 57,9 persen variasi dalam model ini, sedangkan sisanya dipengaruhi oleh variabel di luar model penelitian ini. Sesuai dengan penelitian terdahulu dan hasil temuan ini, menunjukkan bahwa aliran PMA merupakan salah satu determinan penting yang mendorong pertumbuhan ekonomi Indonesia. Oleh karena itu, diharapkan pemerintah pusat dan pemerintah daerah untuk terus berupaya mewujudkan terciptnya iklim investasi yang kondusif, sehingga dapat mendorong investor memiliki ketertarikan berinvestasi di Indonesia.
\end{abstract}

Kata kunci: PMA, PDB, Pertumbuhan Ekonomi, Iklim Investasi

\section{PENDAHULUAN}

Aliran investasi langsung di Indonesia menunjukkan tren yang semakin meningkat. Berdasarkan Siaran Pers Badan Koordinasi Penanaman Modal (BKPM), realisasi investasi Penanaman Modal Dalam Negeri (PMDN) dan Penanaman Modal Asing (PMA) mencapai 692,8 triliun rupiah pada tahun 2017. Capaian tersebut berada di atas target yang telah ditetapkan, yakni sebesar 678,8 triliun rupiah. Dengan capaian ini diharapkan dapat memicu peningkatan target investasi PMDN dan PMA tahun 2018 yang telah ditetapkan oleh pemerintah sebesar 765 triliun rupiah (BKPM, 2018).

Untuk percepatan realisasi investasi PMDN dan PMA, pada tahun 2017 telah dikeluarkan Peraturan Presiden Nomor 91 Tahun 2017 tentang Percepatan Pelaksanaan Berusaha. Perpres tersebut bertujuan untuk memberikan solusi terhadap berbagai permasalahan yang dihadapi oleh investor. Dalam hal ini pemerintah telah membentuk satuan tugas di berbagai Kementerian terkait, Pemerintah Provinsi dan Pemerintah Kabupaten/Kota. Di samping itu, BKPM juga telah menerbitkan Peraturan Badan Koordinasi Penanaman Modal Nomor 13 Tahun 2017 tentang Pedoman dan Tata Cara Perizinan dan Fasilitas Penanaman Modal dan Peraturan Badan Koordinasi Penanaman Modal Nomor 14 Tahun 2017 tentang Pedoman dan Tata Cara Pengendalian Pelaksanaan Penanaman Modal. Kedua peraturan tersebut diharapkan dapat memacu percepatan iklim investasi di Indonesia.

Studi ini menjelaskan perkembangan aliran PMA dan dampaknya terhadap pertumbuhan ekonomi Indonesia. Menurut Mah \& Yoon (2010), untuk kasus di Indonesia, ukuran pasar dan upah tidak berpengaruh signifikan, sedangkan tingkat bunga menunjukkan pengaruh positif dan signifikan 
terhadap aliran PMA. Sementara itu, sebuah hasil kajian yang menggunakan data seri waktu dari tahun 1980-2004, menunjukkan bahwa PMA memiliki pengaruh positif terhadap pertumbuhan ekonomi di Indonesia (Wahyudi, 2009).

Investasi di berbagai bidang akan mendorong perubahan struktur ekonomi di setiap daerah di Indonesia. Hasil penelitian mengenai perubahan struktur ekonomi dengan menggunakan data seri waktu dari tahun 2002-2008 pada 3 kabupaten/kota hasil pemekaran dari Kabupaten Aceh Utara (Kabupaten Aceh Utara, Kabupaten Bireuen, Kota Lhokseumawe) menunjukkan bahwa telah terjadi pergeseran struktur ekonomi daerah (Mardhani, 2014). Selanjutnya, Aswadi, Ratna, Amiruddin, Hasan, \& Mardhani (2017) yang mengkaji tentang perubahan struktur ekonomi di Provinsi Aceh, juga menyatakan bahwa perekonomian Aceh yang sebelumnya bergantung pada sektor primer, telah beralih ke sektor tersier. Hal ini merupakan indikasi dari unjuk kinerja atau peningkatan produktivitas dari sektor-sektor tersebut.

Berdasarkan uraian di atas, maka permasalahan utama dalam kajian ini adalah bagaimana perkembangan aliran PMA dan dampaknya terhadap pertumbuhan ekonomi di Indonesia. Dari permasalahan tersebut, maka penelitian ini bertujuan untuk mengetahui perkembangan aliran PMA dan dampaknya terhadap pertumbuhan ekonomi di Indonesia.

\section{TINJAUAN PUSTAKA}

PMA merupakan cerminan dari ketertarikan dan kendali jangka panjang oleh investor asing, penduduk dalam suatu perekonomian, afiliasi perusahaan asing (UNCTAD, 2017). Aliran masuk PMA berupa modal yang disediakan oleh investor asing ke perusahaan afiliasinya, atau modal yang diterima oleh investor asing dari afiliasi perusahaannya.

Terdapat banyak riset yang menguji mengenai pengaruh aliran PMA ke dalam sebuah perekonomian pada suatu negara terhadap pertumbuhan ekonominya. Hasil penelitian oleh Moudatsou (2003) di negara-negara Uni Eropa mengenai dampak PMA terhadap pertumbuhan ekonomi negaranegara tersebut selama periode 1980-1996, menunjukkan bahwa determinan pertumbuhan bervariasi di seluruh anggota Uni Eropa dan hanya aliran PMA yang memiliki pengaruh signifikan terhadap pertumbuhan ekonomi. Hasil empiris ini menunjukkan bahwa PMA berdampak positif terhadap pertumbuhan ekonomi di Uni Eropa baik secara langsung maupun tidak langsung melalui penguatan perdagangan.

Hal yang sama juga terjadi di Indonesia, dimana tedapat hubungan kausalitas antara PMA dan PDB pada periode 1980-2004. Di samping itu, hasil kajian ini juga menyorot pentingnya aliran PMA dalam perekonomian, dan menyimpulkan bahwa PMA tersebut mempengaruhi pertumbuhan ekonomi Indonesia. Menurut Reza, Fan, Reza, \& Wang (2018), PMA dan Produk Domestik Bruto (PDB) memiliki hubungan kausalitas di Banglades. Di mana kemampuan negara dalam meningkatkan pertumbuhan ekonomi dapat mendorong masuknya aliran PMA yang lebih besar. 
Mah \& Yoon (2010) yang mengungkapkan faktor penentu aliran PMA ke Indonesia dan Singapura. Bukti empiris menujukkan bahwa untuk Indonesia, ukuran pasar dan upah tidak berpengaruh signifikan, sementara tingkat bunga memiliki pengaruh positif dan signifikan secara statistik terhadap aliran PMA. Kurtishi-Kastrati (2013) juga menyorot peran penting PMA dalam perekonomian suatu negara. Ia mengemukakan bahwa setelah Perang Dunia Kedua, PMA telah memiliki peran penting dalam mendorong kinerja perekonomian dunia. Di Zimbabwe, sebagaimana studi yang dilakukan oleh Moyo (2013), menunjukkan bahwa PMA memiliki dampak positif dan signifikan terhadap pertumbuhan ekonomi. Dimana pengeluaran pemerintah dan investasi swasta ditemukan memiliki dampak yang signifikan dan positif terhadap PDB. Hal tersebut juga berlaku di Portugal, yang dibuktikan oleh riset yang dilakukan oleh Leitão (2013), yang mengungkapkan hubungan antara pertumbuhan ekonomi dan PMA. Dengan menggunakan pendekatan data panel, hasilnya menunjukkan bahwa aliran PMA dan perdagangan bilateral mendorong pertumbuhan ekonomi di negara tersebut.

Sementara untuk kasus negara-negara maju, dalam kaitannya dengan kualitas pengembangan perbankan dalam hubungan PMA-pertumbuhan ekonomi, menunjukkan bahwa untuk negara-negara maju PMA berhubungan negatif dengan pertumbuhan ekonomi. Namun, ketika PMA berinteraksi dengan indeks kualitas pengembangan perbankan, kualitas pengembangan perbankan ditemukan memainkan peran positif dalam mempengaruhi efek PMA terhadap pertumbuhan ekonomi (Nor Hakimah, Low, Md Nor, \& Ghazali, 2013).

Melnyk, Kubatko, \& Pysarenko (2014) juga telah meneliti dampak dari investasi langsung asing terhadap perkembangan ekonomi negara-negara dalam perekonomian transisi pasca Comecon. Hasilnya menunjukkan bahwa PMA berpengaruh signifikan terhadap pertumbuhan ekonomi suatu negara. Kajian serupa juga dilakukan Hlavacek \& Bal-Domanska (2016), ia menganalisis PMA dan dampaknya terhadap pertumbuhan ekonomi di negara-negara Eropa Tengah dan Timur selama tahun 2000-2012, dengan penekanan pada Republik Ceko, Estonia, Hongaria, Latvia, Lithuania, Polandia, Slovakia dan Slovenia. Hasil penelitian menunjukkan bahwa, terdapat pengaruh yang rendah dari PMA terhadap perekonomian di Lithuania, Polandia, Latvia, dan Slovenia. Namun riset ini juga membuktikan bahwa ada hubungan yang signifikan secara statistik antara pertumbuhan ekonomi, PMA dan pertumbuhan investasi.

Studi yang dilakukan oleh Pandya \& Sisombat (2017) di Australia yang mengkaji arus masuk PMA dan dampaknya terhadap pertumbuhan ekonomi menunjukkan bahwa, arus masuk PMA berkontribusi pada perekonomian Australia termasuk pertumbuhan dalam PDB, kinerja ekspor dan penciptaan lapangan kerja. Namun demikian, meskipun memiliki kontribusi terhadap perekonomiannya, hasil kajian ini juga menunjukkan bahwa tidak terdapat hubungan kausalitas antara PMA dan pertumbuhan ekonomi. 


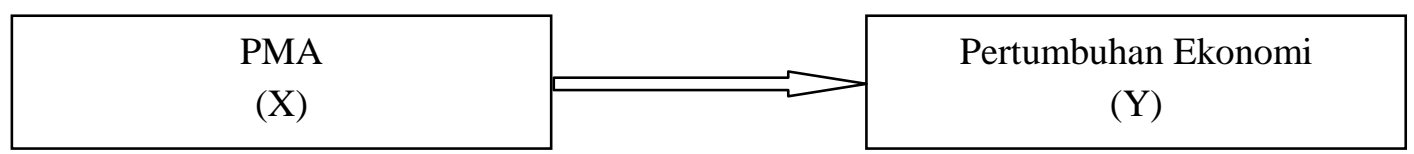

\section{Gambar 1. Kerangka Pemikiran}

Berdasarkan kajian literatur di atas, maka pada Gambar 1 dibuat ilustrasi untuk memudahkan pemahaman terhadap variabel kajian. Di samping itu, dalam penelitian ini juga dirumuskan hipotesis untuk studi ini. Hipotesis dalam studi ini adalah aliran penanaman modal asing (PMA) berpengaruh positif dan signifikan terhadap pertumbuhan ekonomi di Indonesia.

\section{METODE PENELITIAN}

Penelitian ini menggunakan data Produk Domestik Bruto (PDB) sebagai variabel terikat dan Penanaman Modal Asing (PMA) sebagai variabel bebas yang ditulis dalam satuan milyar dolar Amerika Serikat. Data untuk kedua variabel tersebut bersumber dari publikasi World Bank. Metode dalam penelitian ini menggunakan metode analisis kuantitatif dengan pendekatan Ordinary Least Squares (OLS). Model ini akan menjawab permasalahan kajian secara sederhana. Variabel dalam penelitian ini terlebih dahulu diubah dalam bentuk logaritma natural. Selanjutnya menggunakan model berikut (Gujarati \& Porter, 2010):

$Y_{i}=B_{1}+B_{2} X_{i}+u_{i}$

Dimana $Y_{i}$ adalah variabel terikat, $X_{i}$ adalah variabel bebas, $B_{l}$ adalah konstanta, $B_{l}$ adalah koefisien regresi dan $u_{i}$ merupakan error term. Selanjutnya model di atas disesuaikan sebagai berikut:

$\ln P D B=\propto+\beta_{1} \ln P M A+e$

Dimana PDB adalah Produk Domestik Bruto. PMA merupakan Penanaman Modal Asing (PMA), $\propto$ adalah konstanta, dan e adalah error term. Selanjutnya data tersebut diolah dengan menggunakan Eviews10.

\section{HASIL DAN PEMBAHASAN}

Perkembangan Produk Domestik Bruto (PDB) dan Penanaman Modal Asing (PMA) dari tahun 2004-2017 disajikan pada Tabel 1. Nilai PDB sejak periode tersebut semakin meningkat, sebaliknya perkembangan realisasi nilai aliran PMA berfluktuasi sangat tajam.

Sejak periode tersebut, memperlihatkan tren PDB yang semakin meningkat hingga tahun 2012 dan semakin menurun dari tahun 2012-2015. Selanjutnya sejak tahun 2016 kembali meningkat hingga mencapai nilai 1.015,54 Milyar Dollar Amerika Serikat (Gambar 1). Sedangkat tren aliran PMA menunjukkan perkembangan yang sangat fluktuatif. Fenomena tersebut ditampil Gambar 2, dimana meskipun realisasi aliran PMA sempat naik turun, di akhir periode penelitian juga memperlihatkan peningkatan. 
Tabel 1. Perkembangan Produk Domestik Bruto dan Penanaman Modal Asing di Indonesia Tahun 2004-2017

\begin{tabular}{ccc}
\hline Tahun & $\begin{array}{c}\text { Produk Domestik Bruto } \\
\text { (Milyar USD) }\end{array}$ & $\begin{array}{c}\text { Penanaman Modal Asing } \\
\text { (Milyar USD) }\end{array}$ \\
\hline 2004 & 256.84 & 1.90 \\
2005 & 285.87 & 8.34 \\
2006 & 364.57 & 4.91 \\
2007 & 432.22 & 6.93 \\
2008 & 510.23 & 9.32 \\
2009 & 539.58 & 4.88 \\
2010 & 755.09 & 15.29 \\
2011 & 892.97 & 20.56 \\
2012 & 917.87 & 21.20 \\
2013 & 912.52 & 23.28 \\
2014 & 890.81 & 25.12 \\
2015 & 860.85 & 19.78 \\
2016 & 932.26 & 4.54 \\
2017 & $1,015.54$ & 21.46 \\
\hline
\end{tabular}

Sumber: World Bank, 2018

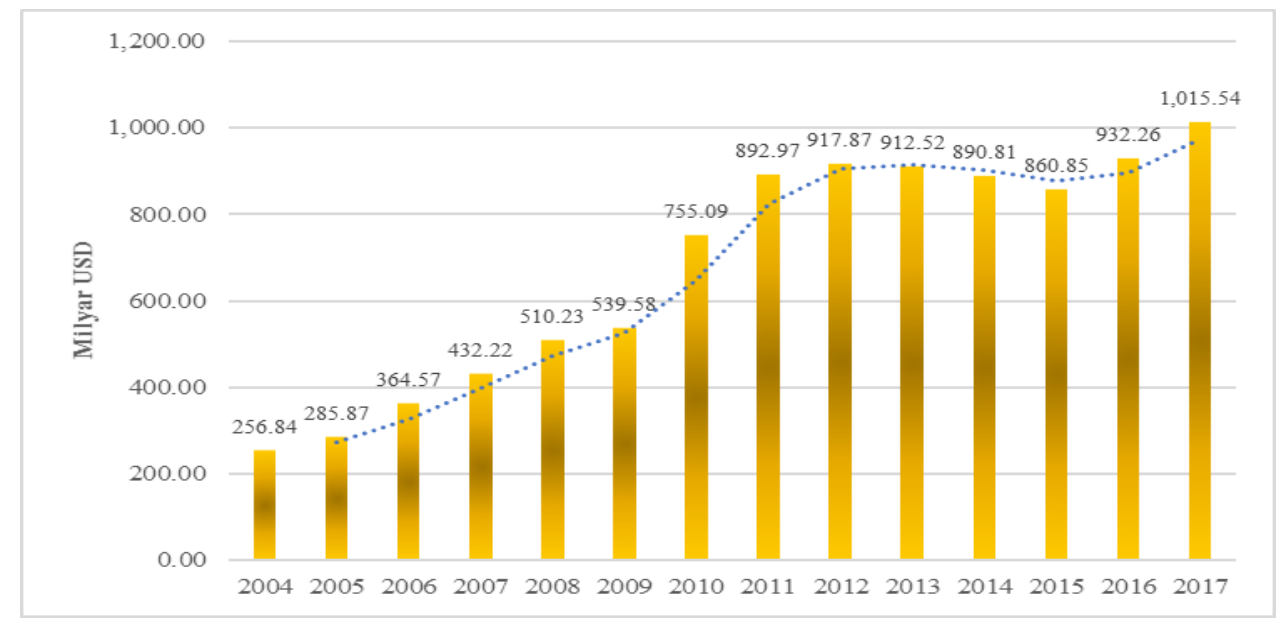

Gambar 2. Perkembangan Produk Domestik Bruto (PDB) Indonesia, 2004-2017

Sumber: World Bank, 2018

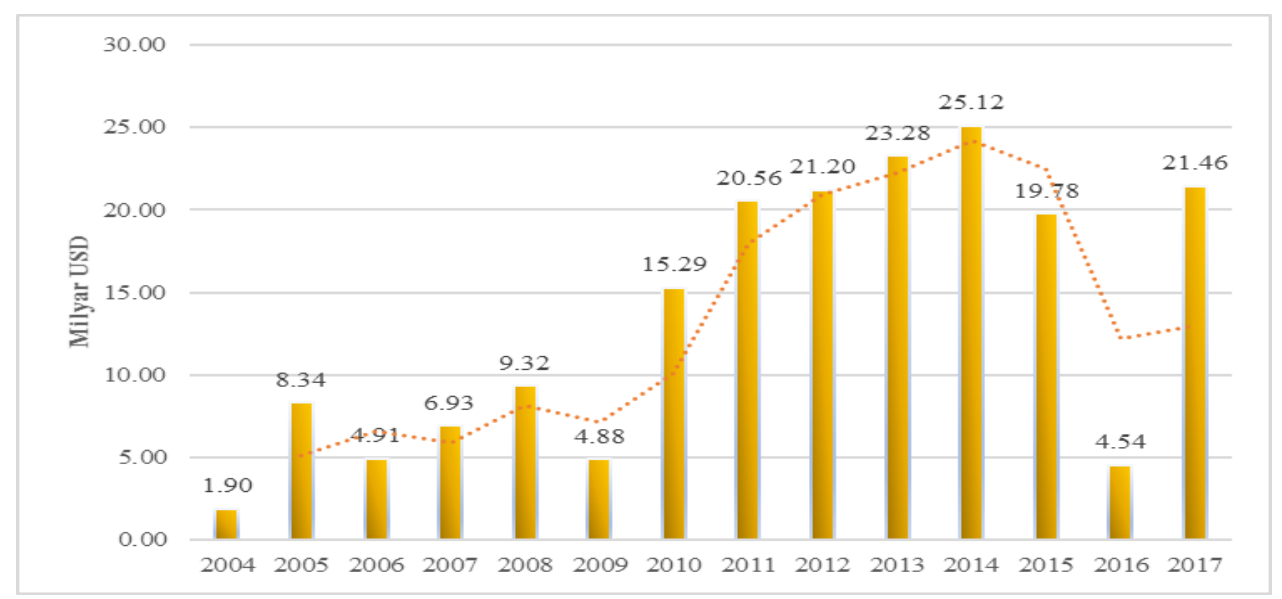

Gambar 3. Perkembangan Aliran Penanaman Modal Asing (PMA) Indonesia, 2004-2017 Sumber: World Bank, 2018 
Berdasarkan hasil dari pengolahan data statistik pada Tabel 2, menunjukkan bahwa pertumbuhan ekonomi Indonesia dipengaruhi oleh variabel aliran PMA. Hal ini dapat dilihat dari hasil uji hipotesis menunjukkan berada di bawah nilai kritis dengan nilai probalitas sebesar 0.000.

Tabel 2. Output Analisis Regresi Linear Sederhana

\begin{tabular}{ccccc}
\hline Variable & Coefficient & Standard Error & T-statistic & Prob. \\
\hline $\ln P M A$ & 0.451698 & 0.111129 & 4.064628 & 0.0016 \\
$\mathrm{C}$ & 5.373684 & 0.274611 & 19.56832 & 0.0000 \\
\hline & R-squared & \\
& 0.579260 & & \\
\hline
\end{tabular}

Sumber: Output Eviews, 2018

Di samping itu, nilai positif dari koefisien dan nilai probabilitas $\alpha \leq 0.5$ dari aliran PMA memberikan gambaran bahwa dengan meningkatnya aliran PMA ke Indonesia, maka akan berdampak pada meningkatnya pertumbuhan ekonomi. Selanjutnya nilai R-square sebesar 0.579 menunjukkan bahwa variasi dalam variabel yang digunakan dapat menjelaskan 57,9 persen pengaruhnya terhadap pertumbuhan ekonomi, sedangkan sisanya dipengaruhi oleh variabel di luar model penelitian ini.

\section{KESIMPULAN DAN SARAN}

Tren PDB yang semakin meningkat hingga periode akhir pengamatan, sebaliknya tren realisasi aliran PMA menunjukkan perkembangan yang sangat fluktuatif. Hal ini disebabkan oleh naik turunnya realisasi PMA di Indonesia selama periode tersebut. Selanjuntnya secara statistik membuktikan bahwa aliran PMA berpengaruh positif dan signifikan terhadap pertumbuhan ekonomi. Selanjutnya nilai koefisien determinasi dapat menjelaskan 57,9 persen variasi dalam model ini, sedangkan sisanya dipengaruhi oleh variabel di luar model penelitian ini. Sesuai dengan penelitian terdahulu dan hasil temuan ini, menunjukkan bahwa aliran PMA merupakan salah satu determinan penting yang mendorong pertumbuhan ekonomi Indonesia. Oleh karena itu, diharapkan pemerintah dan pemerintah daerah untuk terus berupaya mewujudkan terciptnya iklim investasi yang baik, sehingga dapat mendorong investor untuk memiliki ketertarikan berinvestasi di Indonesia.

\section{REFERENSI}

Aswadi, K., Ratna, M., Amiruddin, A., Hasan, I., \& Mardhani, M. 2017. Structural Change in Regional Economies: Empirical Evidenve from Aceh, Indonesia. International Journal of Development and Economic Sustainability. 5(6), 21-30. Retrieved from http://www.eajournals.org/wp-content/uploads/Structural-Change-in-Regional-Economiesmpirical-Evidence-from-Aceh-Indonesia.pdf

Gujarati, D. N., \& Porter, D. C. 2010. Essentials of Econometrics (4th ed.). New York: McGrawHill/Irwin.

Hlavacek, P., \& Bal-Domanska, B. (2016). The Impact of Foreign Direct Investment on Economic Growth of Central and Eastern European Countries. Inzinerine Ekonomika-Engineering Economics. 27(3). 294-303. https://doi.org/10.5755/j01.ee.27.3.3914 
Kurtishi-Kastrati, S. 2013. Impact of Fdi on Economic Growth: an Overview of the Main Theories of FDI and Empirical Research. European Scientific Journal, ESJ. 9(7). 56-77. https://doi.org/10.19044/ESJ.2013.V9N7P\%P

Leitão, N. C. 2013. The Impact of Foreign Direct Investment on Economic Growth: The Portuguese Experience. Theoretical and Applied Economics. XX(1). 51-62. Retrieved from http://store.ectap.ro/articole/815.pdf

Mah, J. S., \& Yoon, S. C. 2010. Determinants of FDI Flows into Indonesia and Singapore. $\begin{array}{lllll}\text { International Area } & \text { Studies } & \text { Review. } & \text { 13(1). }\end{array}$ https://doi.org/10.1177/223386591001300104

Mardhani, M. 2014. Perubahan Struktur Ekonomi Kabupaten Aceh Utara, Kabupaten Bireuen dan Kota Lhokseumawe. Jurnal Serambi Ekonomi Dan Bisnis. 1(1), 11-18. Retrieved from http://ojs.serambimekkah.ac.id/index.php/serambi-ekonomi-dan-bisnis/article/view/657

Melnyk, L., Kubatko, O., \& Pysarenko, S. 2014. The Impact of Foreign Direct Investment on Economic Growth: Case of Post Communism Transition Economies. Problems and Perspectives in Management. 12(1). 17-24.

Moudatsou, A. 2003. Foreign Direct Investment and Economic Growth in the European Union. Journal of Economic Integration. 18(4). 689-707.

Moyo, T. 2013. The Impact of Foreign Direct Investment on Economic Growth: The Case of Zimbabwe (2009-2012). International Journal of Economics, Finance and Management Sciences. 1(6). 323-329. https://doi.org/10.11648/j.ijefm.20130106.19

Nor Hakimah, H. M. N., Low, S.-W., Md Nor, A. H. S., \& Ghazali, N. A. 2013. FDI and Economic Growth - Does The Quality of Banking Development Matter? Gadjah Mada International Journal of Business. 15(3). 287-303. https://doi.org/10.1016/S1097-2765(00)80224-5

Pandya, V., \& Sisombat, S. 2017. Impacts of Foreign Direct Investment on Economic Growth: Empirical Evidence from Australian Economy. International Journal of Economics and Finance. 9(5). 121-131. https://doi.org/10.5539/ijef.v9n5p121

Reza, S. M., Fan, H., Reza, T., \& Wang, B. (2018). The Impact of Foreign Direct Investment on Economic Growth in Jordan. Journal of Business and Retail Management Research. 12(2). 212-223. Retrieved from http://arpapress.com/Volumes/Vol8Issue2/IJRRAS_8_2_16.pdf

UNCTAD. (2017). Fact sheet \# 9: Foreign direct investment. In UNCTAD Handbook of Statistics 2017 - Economic trends. Retrieved from https://unctad.org/en/PublicationChapters/tdstat42_FS09_en.pdf

Wahyudi, S. T. 2009. The Impact of Foreign Direct Investment on Economic Growth in Indonesia, 1980-2004: A Causality Approach. Journal of Indonesian Economy and Business. 24(3). 311327. https://doi.org/10.21511/ppm.14(2-2).2016.04

World Bank. 2018a. Foreign Direct Investment, Net Inflows (BoP, Current US\$). Retrieved October 10, 2018, from https://data.worldbank.org/indicator/BX.KLT.DINV.CD.WD?view=chart

World Bank. 2018b. GDP (current US\$). Retrieved October 10. 2018. from https://data.worldbank.org/indicator/NY.GDP.MKTP.CD?view=chart 